\title{
Features of suspended matter distribution at the atmosphere-water boundary in the Atlantic and Southern Oceans
}

\author{
Inna A. Nemirovskaya ${ }^{1}$ and Vyacheslav V. Gordeev ${ }^{1}$ \\ Received 20 May 2021; accepted 21 September 2021; published 24 October 2021.
}

The new results of studying the particle size distribution of aerosol, suspended matter and organic compounds in the suspended matter of surface waters of the South and Atlantic Oceans along the Africa-Antarctic-Southern America-English Channel route are presented. The measurements show that the fraction of $0-3 \mu \mathrm{m}$ prevails in the particle size distribution of aerosols. The maximum amount of aerosols was found in the coastal regions of Europe (on average 29,353 p/L), and the minimum - in the coastal regions of Antarctica (on average $5197 \mathrm{p} / \mathrm{L})$, that is due to the Antarctic ice cover on the continent. In surface waters, the distribution of suspended particulate matter and organic matter in it is mainly influenced by the frontal zones. In the Antarctic region, the development of phytoplankton at the ice - water interface in the surface water layer leads to an increase in the concentrations of suspended particulate matter and chlorophyll a and, to a lesser extent, of lipids and hydrocarbons. In the open waters of the arid oceanic zones, the influx of aerosols from the atmosphere has the most significant effect on the formation of suspended matter and organic matter in surface waters in comparison with the another parts of the oceans. KEYWORDS: Aerosols; surface water; suspended particulate matter; organic matter; $C_{\text {org }}$; chlorophyll a; lipids; hydrocarbons.

Citation: Nemirovskaya, Inna A. and Vyacheslav V. Gordeev (2021), Features of suspended matter distribution at the atmosphere-water boundary in the Atlantic and Southern Oceans, Russ. J. Earth. Sci., 21, ES5005, doi:10.2205/2021ES000777.

\section{Introduction}

Aeolian material in surface waters mixes with suspended particulate matter (SPM) and is included in the vertical and horizontal streams. Therefore, the atmosphere - water geochemical barrier zone is an important area of the oceanic sedimentation system [Butler and Coyne, 2016. Gogou et al., 1998; Gooseff et al., 2002 Lisitsyn, 2014. It was found that the contribution of aerosols to the formation of sedimentary material is close to the contribution of river suspension outside the zone of the river-sea geochemical barrier [Lisitsyn, 2014]. The

\footnotetext{
${ }^{1}$ Shirshov Institute of Oceanology RAS, Moscow, Russia
}

Copyright 2021 by the Geophysical Center RAS. http://rjes.wdcb.ru/doi/2021ES000777-res.html sea surface is also a powerful source of aerosols generated by wave breaking and high winds [Massel, 2007 Stokes et al., 2013; Vasilenko et al., 1985. So, this zone is an active one in the interchange of sedimentary material between air and water. The surface layer of the ocean, as the most dynamic part of it, responds faster to changing environmental conditions. Despite a relatively small share in the total volume of the ocean, the mechanisms of the global oceanic conveyor are triggered in the surface layer, affecting its entire thickness [Lappo et al., 2003. In addition, most of the organic matter (OM) and about 110 billion tons of SPM are produced here [Lisitsyn, 2014]. At the same time, many factors influence its distribution [Anglada et al., 2020, Pedrosa-Pamiesa et al., 2018, Van Eijk et al., 2011. Therefore, the detailed investigations of the atmosphere - water geochemical barrier zone attract attention of the researchers. The satellite 
(a)

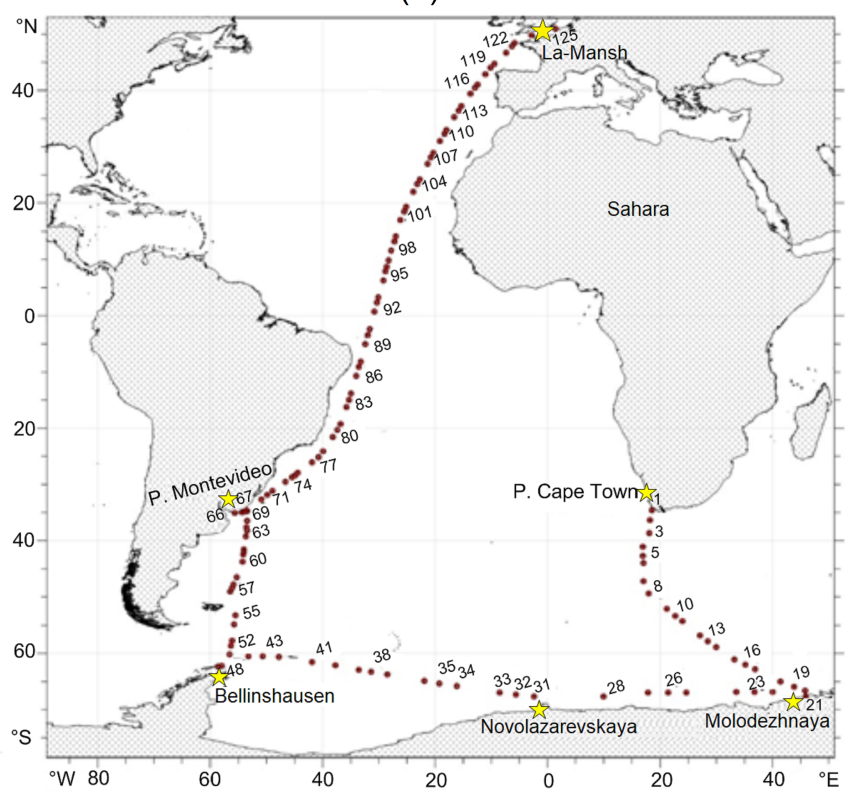

(b)

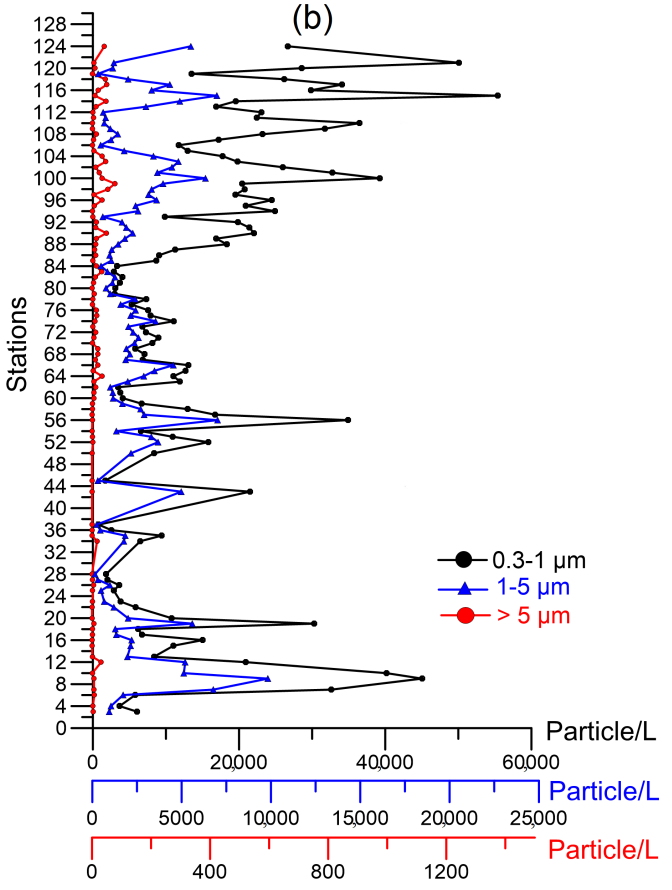

Figure 1. Location of aerosol sampling stations along the route of the R/V Akademik Fedorov - (a) and distribution of the particle size of the surface layer aerosol - (b).

sensing methods, actively used to study the surface layer of the ocean, are needed in the data verification, and don't allow to make the measurements of the SPM and organic compounds (OCs) contents with sufficient accuracy [Klyuvitkin, 2008, Klemas and Yan, 2014, Lisitsyn, 2014. The latter also dictates the need to collect information about their content in the near-surface layer of the atmosphere and in surface waters.

Atmospheric aerosols are represented by the aggregates of tiny particles or liquid droplets suspended in the gas phase [Brimblecombe et al., 2020. They interact with water vapor, serve as condensation nuclei in cloud formation processes and enrich the atmosphere with water-soluble components [Yoshizue et al., 2019]. Despite the fact that the aerosol is one of the minor atmospheric impurities, it is the most dynamic component of the atmosphere [Golobokova et al., 2016, Ivlev and Dovgalyuk, 1999, Lisitsyn, 2014. The study of SPM in the water column is necessary to understand the processes of sedimentation and to assess the ecological state of the water area. In addition, aerosol and marine SPM are often the main carriers of pollution in the sea [Lohmann, 2013, Lohmann and Belkin, 2014, Nemirovskaya, 2013. Precipitation is very effective agent of the aerosol and gaseous impurities removal from atmosphere.

Investigations of aerosols and surface water can be studied along the route of the vessel [Klyuvitkin, 2008. Nemirovskaya, 2013, 2017, since along the way of its movement there is an interaction of 4 spheres: the atmosphere, hydrosphere, biosphere and cryosphere. OCs are the important components of aerosols. They can absorb (or scatter) light, contributing to warming or cooling, that is, they affect climatic changes [Goudie and Middleton, 2001, the atmospheric radiation budget [Wozniak et al., 2014. This is due to the molecular composition of the OCs of aerosols coming from different sources.

The main purpose of the study is to determine the influence of aeolian inputs and frontal zones of the Southern and Atlantic oceans on the distribution of SPM and the main components of the OCs ( $C_{\text {org }}$, lipids, hydrocarbons - HCs, chlorophyll $a-$ $\mathrm{Chl} a$ ) in the near-surface layer of the atmosphere and in the suspended matter of surface waters.

The data were obtained in March-June 2019 along the route of the $\mathrm{R} / \mathrm{V}$ Akademik Fedorov in the Atlantic and Southern Oceans (Figure 1). 


\section{Materials and Methods}

On the route of the $\mathrm{R} / \mathrm{V}$ Akademik Fedorov (March-June 2019) in the Atlantic and Southern Oceans (Figure 1) in the 64th Russian Antarctic Expedition (RAE), the particle size distribution of the drive aerosol was studied (Figure 1a). For this, an AeroTrak particle counter ("TSI Inc.", USA) was used, which makes it possible to obtain the composition of aerosols in the near water layer (height was $18 \mathrm{~m}$ from water surface) of the atmosphere through three channels: $0.3-1 ; 1.0-5.0$ and $>5 \mu \mathrm{m}$. From 2 to 8 measurements were performed daily, depending on weather conditions. The wind speed and direction were measured in parallel. In addition, surface water samples were taken (3 times during daylight hours), in which the concentration and composition of marine suspended matter and OCs in it were determined.

On the Antarctica mainland, the samples of mosses and lichens were taken, which sorb organic compounds from atmosphere. The analysis of soil samples, on which the lichens and mosses were found, was carried out according to the same scheme: they were dried at $50^{\circ} \mathrm{C}$, ground in an agate mortar, and OCs was extracted from the suspended fraction (about g) with methylene chloride. Further HCs determination was carried out in the same way as in SPM.

To determine the concentrations of OCs, the samples of surface water (about 0-0.3 m layer) were filtered GF/F glass-fiber filters $(0.7 \mu \mathrm{m})$ that were calcined for $6 \mathrm{~h}$ at $450^{\circ} \mathrm{C}$. The SPM was separated from the water by membrane filtration. The filters were preliminarily washed with a $0.1 \mathrm{~N} \mathrm{HCl}$ of high purity and then with double distilled water. Samples were filtered under 0.4 atm pressure and concentrations were then determined gravimetrically.

All solvents were of high purity level. Methylene chloride was used to extract lipids from the water and SPM. The individual AHCs fractions were separated with hexane by means of column chromatography on silica gel. The concentrations of lipids and HCs (before and after the chromatography, respectively) were determined by IR spectroscopy using an IR Affinity 1 (Shimadzu, Japan). A mixture (by volume) was used as a standard: $37.5 \%$ isooctane, $37.5 \%$ hexadecane, and $25 \%$ benzene (Simard mixture) [Korshenko, 2019, Simard, 1951. This method is used as an arbitration method for the analysis of petroleum HCs [Korshenko, 2019]. The sensitivity of the method is $3 \mu \mathrm{g} / \mathrm{ml}$ of extract.

The concentration of Chl $a$ was determined by the fluorescence method using a Trilogy instrument from Turner (USA) [Arar and Collins, 1997]. To isolate chlorophylls, the filters were placed in $90 \%$ acetone at $+4^{\circ} \mathrm{C}$ and kept in dark for 12-16 hours, after which the fluorescence was measured. To correct the Chl $a$ concentration, taking into account the pheo pigment (Pheo $a$ ), the extract was acidified with $1 \mathrm{~N} \mathrm{HCl}$, and the fluorescence intensity was determined once more.

$C_{\text {org }}$ in the samples of the SPM was determined by dry combustion with an AN-7560 analyzer (Russia). A filter or its fragment was placed into a porcelain crucible; then common procedures for determining $C_{\text {org }}$ in bottom sediments were used. The sensitivity amounted to $6 \mu \mathrm{g}$ of carbon in a sample at a precision of $3-6 \%$.

\section{Results}

In the near surface water layer a number of aerosol particles for the fraction of $0.3-1 \mu \mathrm{m}$ was varied almost 76 times in a range from 732 to $55,389 \mathrm{p} / \mathrm{L}$ depending on the research area along route of the expedition (Table 1$)$.

Africa-Antarctica. The Africa-Antarctica section crossed the frontal zones of the Southern Ocean. The Antarctic Circumpolar Current (ACC) is the main element of the large-scale water circulation in the southern polar region. The zonal flow of the ACC provides interconnection and similarity of the regimes of the southern parts of the Atlantic, Indian, and Pacific oceans, which became the basis for their unification into an independent object - the Southern Ocean [Antipov and Klepikov, 2011 Deacon, 1982, Demidov et al., 2007; Orsi et al., 1995. The following frontal zones are established within the ACC: the Agulhas Current (FTAG), Subtropical (STF), Subantarctic (SAF), Polar (PF), South Frontal Zone (SF), Antarctic Divergence (AD), which is taken as the southern border of the Antarctic zone (Figure 2). These fronts are the complex system of vortex formations interacting with each other, areas of convergence and divergence.

The data obtained showed that when crossing the FTAG current, which brings warm waters from 
Table 1. The Concentrations of Near-Water Surface Layer Aerosols (Particles/L) in Different Regions of the Southern Ocean and the Atlantic Ocean Along the Route

\begin{tabular}{|c|c|c|c|c|}
\hline Region & $\begin{array}{l}\text { Number of } \\
\text { samples }\end{array}$ & $\begin{array}{l}0.3-1 \mu \mathrm{m} \\
\text { interval } \\
\text { average }\end{array}$ & $\begin{array}{l}1-5 \mu \mathrm{m} \\
\text { interval } \\
\text { average }\end{array}$ & $\begin{array}{l}>5 \mu \mathrm{m} \\
\text { interval } \\
\text { average }\end{array}$ \\
\hline \multicolumn{5}{|c|}{2019} \\
\hline Africa-Antarctic & 14 & $\frac{3663-45,034}{17,841}$ & $\frac{947-9826}{3370}$ & $\frac{0-31}{5}$ \\
\hline Antarctica & 12 & $\frac{792-21,519}{6182}$ & $\frac{156-4977}{1117}$ & $\frac{0-17}{2}$ \\
\hline Antarctica to & 4 & $\underline{6591-15,799}$ & $\underline{1341-3681}$ & $\underline{0-3}$ \\
\hline South America & & 20,143 & 2622 & 1 \\
\hline Coastal zone of & 35 & $\underline{2896-34,893}$ & $\underline{484-7009}$ & $\underline{0-34}$ \\
\hline South America & & 8682 & 2218 & 10 \\
\hline Central Atlantic & 11 & $\frac{9867-33,824}{23,754}$ & $\frac{583-4356}{2783}$ & $\frac{1-78}{27}$ \\
\hline $\begin{array}{l}\text { Canary upwelling } \\
\text { area }\end{array}$ & 6 & $\frac{12,984-32,742}{16,618}$ & $\frac{1040-4822}{3196}$ & $\frac{5-46}{22}$ \\
\hline Coastal zone & 14 & $\underline{10,368-55,389}$ & $\underline{328-6973}$ & $\underline{0-50}$ \\
\hline of Europe & & 28,186 & 2256 & $\overline{16}$ \\
\hline the English Channel & 1 & 26,692 & 5510 & 42 \\
\hline \multicolumn{5}{|c|}{2015 [Nemirovskaya, 2017} \\
\hline Coastal zone of & 92 & $\underline{1193-60,353}$ & $\underline{256-5373}$ & $\underline{0-1247}$ \\
\hline South America & & 10,399 & 1450 & 46 \\
\hline Central Atlantic & 56 & $\frac{1865-34,183}{18,311}$ & $\frac{531-5367}{2055}$ & $\frac{0-167}{8}$ \\
\hline $\begin{array}{l}\text { Canary upwelling } \\
\text { area }\end{array}$ & 44 & $\frac{3575-27,257}{9573}$ & $\frac{172-2830}{964}$ & $\frac{0-39}{4}$ \\
\hline $\begin{array}{l}\text { Coastal zone } \\
\text { of Europe }\end{array}$ & 50 & $\frac{2315-15,319}{6419}$ & $\frac{84-2231}{718}$ & $\frac{0-19}{2}$ \\
\hline $\begin{array}{l}\text { North and Baltic seas, } \\
\text { including the } \\
\text { English Channel }\end{array}$ & 76 & $\frac{3825-147,067}{36,613}$ & $\frac{202-4128}{1520}$ & $\frac{0-609}{34}$ \\
\hline
\end{tabular}

the northern regions of the Indian Ocean with a lower productivity, there was a decrease in both aerosols and all compounds in surface waters Figure 2 a). In the water area of the African continent, there was a local maximum of the near-water aerosol $(32,648 \mathrm{p} / \mathrm{L}$ for the $0.3-1 \mu \mathrm{m}$ fraction) in the northern arid part of the section, due to the circum-continental zoning. Here, in addition to terrigenous suspension, the removal of anthropogenic particles from the Port of Cape Town is also possible. In addition, at a high wind force $(>20 \mathrm{~m} / \mathrm{s})$, foam and particles are strongly blown out from the sea surface, which increases their total amount in the atmosphere.

However, the highest concentration of aerosols in this section was found in the SF region $(45,034$ $\mathrm{p} / \mathrm{L}$ ) at a maximum wind speed of $25 \mathrm{~m} / \mathrm{s}$. The aerosol content was changed most chaotically in the southern part of the section.

In surface waters, as the STF was crossed, the amount of all studied compounds was increased, since here cold, more productive subantarctic wa- 
(a)

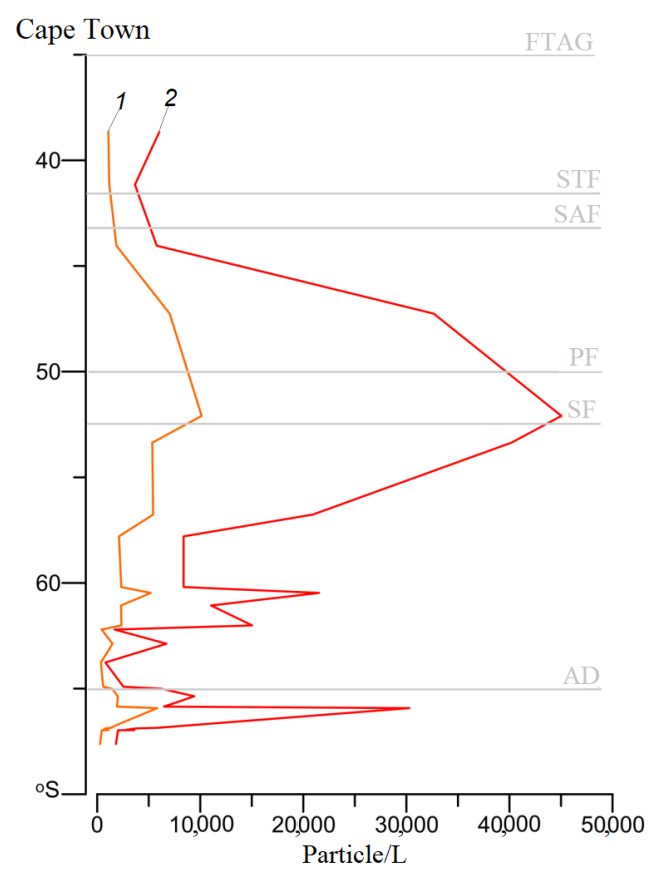

(b)

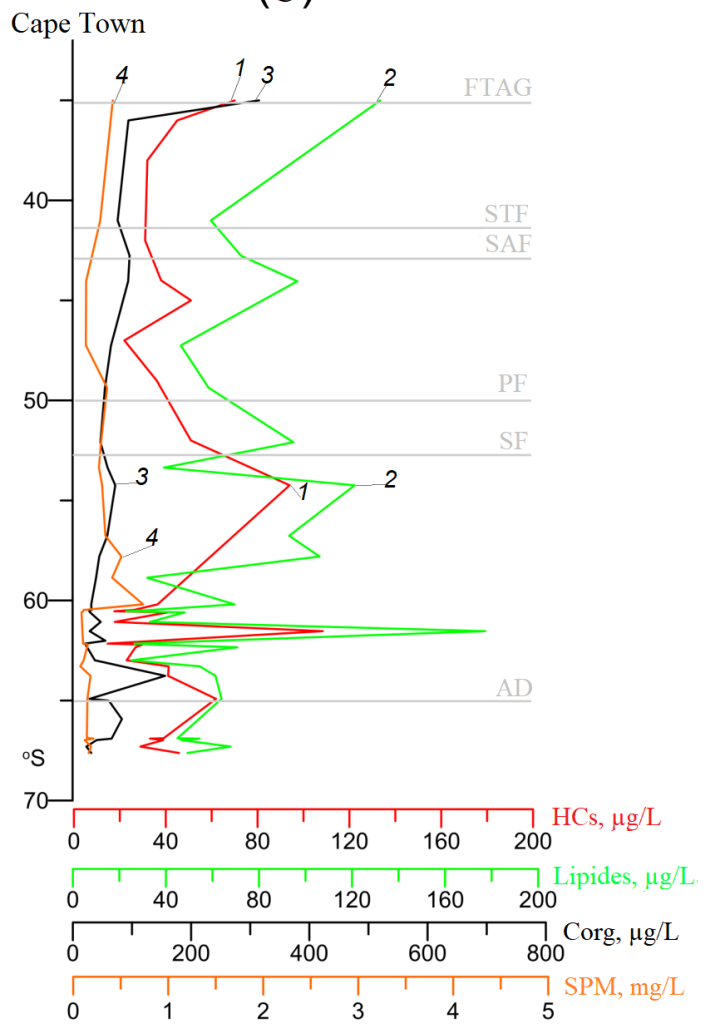

Figure 2. Distribution of aerosols (a): $1-0.3-1,2-1-5 \mu \mathrm{m}$ and organic compounds and suspended matter in surface waters (b) in the section Africa (Cape Town)-Antarctica. 1 - HCs, 2 - lipids, 3 - $C_{\text {org }}, 4$ - SPM.

ters were risen to the surface [Demidov et al., 2007]. At the same time, the amount of SPM was varied in antiphase with temperature [Nemirovskaya and Artem'ev, 2013.

After crossing SAF, the distribution of SPM and TC demonstrated maximum in the region of 53 $55^{\circ} \mathrm{S}$ (Figure $2 \mathrm{~b}$ ) associated with the focus of vortex formations. The increase in water productivity in this area is consistent with an increase in the content of Chl $a$. Its concentration reached values of $0.5 \mu \mathrm{g} / \mathrm{L}$ against the background values of 0.1 $0.2 \mathrm{\mu g} / \mathrm{L}$. In the subantarctic climatic zone (on the southern border of the SAF), the gradual cooling of surface waters was accompanied by a decrease in their productivity and a decrease in the concentrations of SPM and Chl $a$.

An increase in the concentrations of all compounds began when we approached the PF, with maximum values in the SF. The mass development of fluorescent microalgae was recorded here [Maslennikov, 2003]. The processes of meandering of the main fronts and the associated vortex formation in the ACC zone generate vortices of different signs in the surface layer of water. The upward and downward movements of surface waters increase or decrease the concentration of nutrients, thereby affecting the growth rate of phytoplankton [Maslennikov, 2003, and, in turn, on the content of suspended matter and organic matter. The greatest variability in their concentrations in surface waters, as well as in aerosols, is occurred in the southern part of the section.

Antarctica. Usually, the main source of atmospheric pollution in the Antarctic coastal regions is sea salt coming from ocean water [Vasilenko et al., 1985 as well as specific Antarctic flora and microorganisms. The aeolan transport of terrigenous $\mathrm{HCs}$ (in the form of higher ground vegetation residuals) from the American and African continents is insignificant. Along the whole vessel route, the particles of $0.3-1.0 \mu \mathrm{m}$ are tradition- 

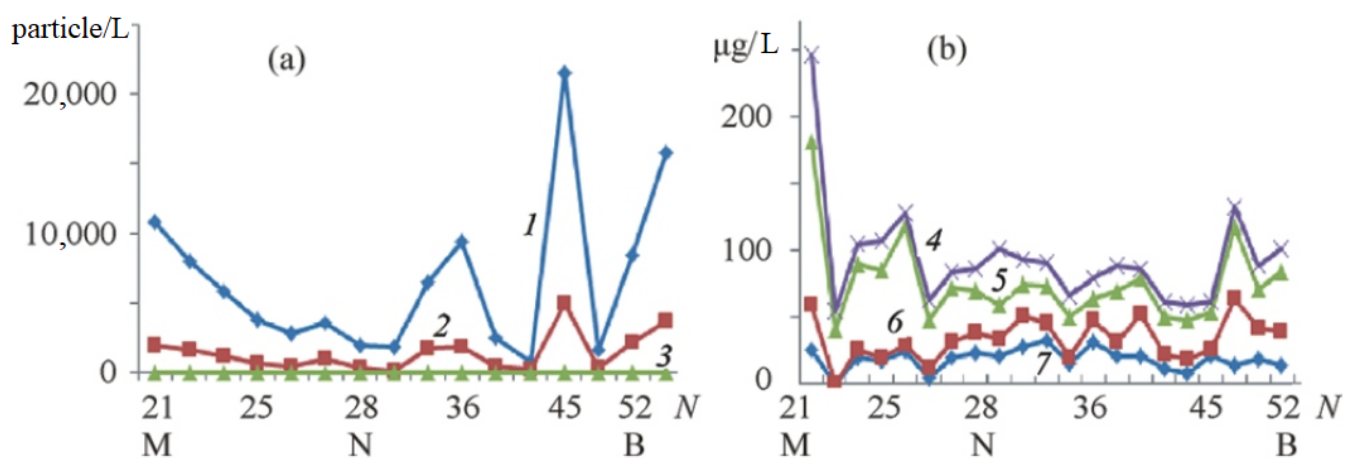

Figure 3. Distribution of aerosols (a) and organic compounds and suspended matter in water surface (b) in the area of Antarctica: $1-0.3-1,2-1-5$, and $3->5 \mu \mathrm{m}, 4-\mathrm{SPM}$ $\left(\times 10^{-1}\right), 5-C_{\text {org }}, 6-\mathrm{Chl} a(\times 100)$, and $7-$ HCs.

ally prevailed (Table 1) [Antipov et al., 2014, Nemirovskaya, 2006]. In particular in 2019 the contribution of surface aerosol particles of $0.3-1.0 \mu \mathrm{m}$ to the total number of particles made up $76-92 \%$.

Particularly, when approaching Bellingshausen Station, the number of particles of this fraction was increased by more than 27 times - up to 21,519 $\mathrm{p} / \mathrm{L}$ (Figure $3 \mathrm{a})$. Besides this, in case of high wind speed, the foam and particles are blown out of the sea surface, and their total number in the atmosphere increases (this probably occurred between stations 34-37, Figure 3).

As moving towards the Weddell Sea the concentrations of all components were increasing. In this area all types of the fronts are presented in a rather small water area, and ideal conditions for the phytoplankton development are formed [Maslennikov, 2003. The latter causes an increase in the concentration of SPM and $C_{\text {org }}$ in SPM (Figure $3 \mathrm{~b}$ ). According to the data obtained with the use of the electronic microscope, SPM in the area of Bellingshausen Station is represented mainly by biogenic particles, like well-preserved skeletons of diatoms with the size of 10-20 $\mathrm{\mu m}$, which made up a significant part of the sample (Figure 4). Along with biogenic particles, the submicron alumosilicate clayey particles from the group of smectites, mixed with organic matter covering all other particles to a different degree, were detected. The gross amount of clayey matter in SPM does not exceed $3 \%$ of the sample volume. In addition, large mineral angular particles $(\sim 10 \%)$ in the form of the sharp-edge isometric pieces with the size of 20-45 $\mu \mathrm{m}$ were detected in the samples (Figure 4 a).
On the contrary, SPM in the area of Molodezhnaya station was consisted from biogenic particles only: diatoms with the size of $10-20 \mu \mathrm{m}$, with the single fragments of bug-eyed fish pellets (Figure $4 \mathrm{~b}$ ).

The concentration of HCs in the surface waters of the Antarctica coast was varied within $5-31 \mathrm{\mu g} / \mathrm{L}$ (the mean value $-19 \mu \mathrm{g} / \mathrm{L}, n=20$, Table 2 ) in 2019. The standard deviation $(\sigma=7 \mu \mathrm{g} / \mathrm{L})$ made up $35 \%$ of the mean value. The concentration of HCs is correlated with the concentration of lipids $(r=0.65, P=0.95)$ but, to a smaller degree, with the content of SPM, $C_{\mathrm{org}}$, and Chl $a(r=$ $0.07-0.23, n=25)$.

On the Antarctic continent, the OC concentrations increased in lichens and mosses. Lichens, without a root system, feed exclusively on substances coming from the atmosphere, and mosses - from the atmosphere and soil. The content of $C_{\text {org }}$ in them (8.99-20.2\%) was much higher than in soils $(0.045-0.101 \%)$. In the harsh conditions of Antarctica, lichens are characterized by sufficient biological activity. The composition of alkanes was dominated by odd homologues (Figure $5 \mathrm{a}$ ). The ratio of low- to high-molecular-weight alkanes was lower than in soils, as well as the CPI values (ratio of odd to even homologues in the high-molecularweight region), that did not exceed 3.88 .

The composition of PAHs in moss samples was similar one (Figure 5b): at total contents of 19$83 \mathrm{ng} / \mathrm{g}$, only low molecular weight homologues were determined, with two maxima: for 1-methylnaphthalene and phenanthrene. The $\mathrm{N} / 1 \mathrm{~N}$ ratio fluctuated in a range $0.11-0.14$, and the share of 
Table 2. Content of organic compounds $(\mu \mathrm{g} / \mathrm{L})$ and suspended matter $(\mathrm{mg} / \mathrm{L})$ in the sections in the surface waters of the Atlantic and Southern oceans

\begin{tabular}{|c|c|c|c|c|c|c|c|}
\hline Period & Area & $\begin{array}{l}\text { Number of } \\
\text { samples }\end{array}$ & $C_{\text {org }}$ & Lipids & $\mathrm{HCs}$ & Chlorophyll $a$ & $\begin{array}{c}\text { Suspended } \\
\text { particulate matter }\end{array}$ \\
\hline \multicolumn{8}{|c|}{ 2015, Academik Ioffe, [Nemirovskaya, 2017] } \\
\hline 27-30 March & $\begin{array}{c}\text { Ushuaia - } \\
\text { El-Rincon Bay }\end{array}$ & 11 & $\frac{45-171}{96}$ & $\frac{21-44}{35}$ & $\frac{15-33}{19}$ & $\frac{0.24-1.03}{0.38}$ & $\frac{0.19-0.45}{0.28}$ \\
\hline $\begin{array}{l}31 \text { March- } \\
3 \text { April }\end{array}$ & Bay El-Rincon & $\begin{array}{c}8 \\
116\end{array}$ & $\frac{83-258}{39}$ & $\frac{27-53}{9}$ & $\frac{5-15}{0.868}$ & $\frac{0.30-2.48}{4.56}$ & $\underline{0.26-9.46}$ \\
\hline 4 April & $\begin{array}{l}\text { The influence } \\
\text { of r. La-Plata }\end{array}$ & 4 & $\frac{64-100}{86}$ & $\frac{21-39}{27}$ & $\frac{3-28}{11}$ & $\frac{0.02-0.40}{0.07}$ & $\frac{0.06-0.14}{0.09}$ \\
\hline 5-16 April & $\begin{array}{l}\text { r. La Plata - } \\
\text { the equator }\end{array}$ & 33 & $\frac{16-64}{26}$ & $\frac{12-47}{17}$ & $\frac{3-28}{10}$ & $\frac{0.02-0.16}{0.06}$ & $\frac{0.06-0.14}{0.09}$ \\
\hline 17-26 April & $\begin{array}{l}\text { equator - } \\
\text { La-Mansh }\end{array}$ & 18 & $\frac{39-69}{47}$ & $\frac{13-31}{23}$ & $\frac{5-25}{14}$ & $\frac{0.03-0.19}{0.10}$ & $\frac{0.07-0.26}{0.12}$ \\
\hline 1-3 May & La-Mansh & 7 & $\frac{31-362}{157}$ & $\frac{8-168}{67}$ & $\frac{5-100}{37}$ & $\frac{0.30-1.30}{0.57}$ & $\frac{0.18-4.40}{1.35}$ \\
\hline 3-6 May & $\begin{array}{l}\text { North, } \\
\text { Baltic seas }\end{array}$ & 11 & $\frac{72-313}{161}$ & $\frac{26-54}{36}$ & $\frac{7-32}{19}$ & $\frac{0.28-2.80}{0.92}$ & $\frac{0.22-1.07}{0.54}$ \\
\hline \multicolumn{8}{|c|}{ 2019, Academik Fedorov } \\
\hline 20-27 March & $\begin{array}{c}\text { Cape Town - } \\
\text { Antarctica }\end{array}$ & 20 & $\frac{39-315}{80}$ & $\frac{2-132}{65}$ & $\frac{1-70}{35}$ & $\frac{0.13-1.71}{0.42}$ & $\frac{0.087-0.736}{0.267}$ \\
\hline 31 March- & Along & 25 & $\underline{15-156}$ & $\underline{23-177}$ & $\underline{9-108}$ & $\underline{0.027-0.501}$ & $\underline{0.075-0.736}$ \\
\hline 1 May & Antarctica & & 46 & 59 & 40 & 0.158 & 0.19 \\
\hline 1-27 May & $\begin{array}{c}\text { Section through } \\
\text { The Atlantic }\end{array}$ & 62 & $\frac{31-130}{83}$ & $\frac{22-124}{57}$ & $\frac{7-71}{23}$ & $\frac{0.06-1.02}{0.38}$ & $\frac{0.022-1.548}{0.230}$ \\
\hline
\end{tabular}

naphthalenes was $63-68 \%$, which indicated the influence of oil arenas.

Antarctica-the English Channel. When the ship moved northward the amount of aerosols were increased arbitrary reaching maximum values of $0.3-1 \mu \mathrm{m}$ fractions $-34,893 \mathrm{p} / \mathrm{L}($ Figure $6 \mathrm{a}$, St. 56) at a maximum of wind speed up to 20.6 $\mathrm{m} / \mathrm{s}$. Reduced concentrations of aerosol particles (3541 p/L, St. 60) were observed at wind speed of $3.1 \mathrm{~m} / \mathrm{s}$.

At approach to the shore, the concentrations of aerosols were increased. Therefore, in the La Plata Bay (Montevideo port), a higher aerosol content $(11,914 \mathrm{p} / \mathrm{L})$ was registered at a wind speed of only $1.8 \mathrm{~m} / \mathrm{s}$. Nevertheless, the maximum concentrations of aerosols in this area $(13,045 \mathrm{p} / \mathrm{L})$ were observed at wind speed values of $9.4 \mathrm{~m} / \mathrm{s}$. In the Atlantic Ocean with distance from the mainland the amount of aerosols was decreased randomly varying in a range of $2655-10,094 \mathrm{p} / \mathrm{L}$ with minimum values fixed at St. 83 with a wind speed of $4.8 \mathrm{~m} / \mathrm{s}$ only.

The changes in wind direction also lead to a change in the amount of aerosols in the atmosphere. Particularly, at stations 84 and 85, when the wind direction was changed from $135^{\circ}$ to $38^{\circ}$ with its practically steady speed $(9-10 \mathrm{~m} / \mathrm{s})$, the contents of aerosols were increased almost 2 times, ranging from 3289 to $8686 \mathrm{p} / \mathrm{L}$.

In the area $17-18^{\circ} \mathrm{N}$, influenced by the flows from African desert (stations 100-102), the contents of aerosols were exceeded $30,000 \mathrm{p} / \mathrm{L}$. In humid areas, the aerosol fluxes first was decreased, and then was again increased under the influence of anthropogenic inputs from industrial European regions (Figure 6a). The highest aerosol content $(52,990$ $55,389 \mathrm{p} / \mathrm{L}$ ) is confined to the Bay of Biscay (sta- 

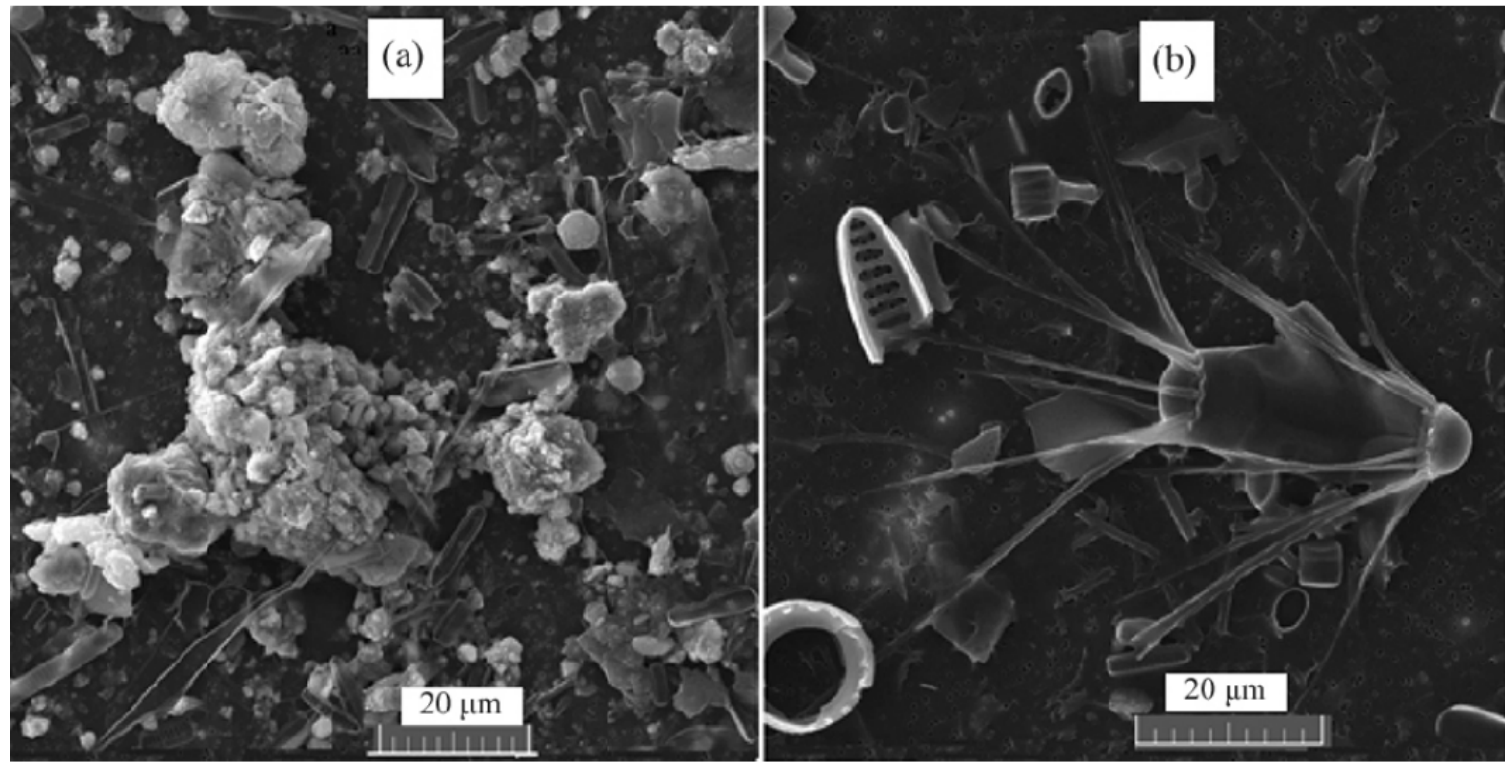

Figure 4. The composition of suspended matter in surface water in the area of (a) Bellingshausen and (b) Molodezhnaya stations. $N$ is the station number; M is Molodezhnaya; $\mathrm{N}$ is Novolazarevskaya; B is Bellingshausen.

tions 114-115). In the English Channel, concentrations were lower $(26,692 \mathrm{p} / \mathrm{L})$, probably because of the last rains.

In surface waters the concentrations of the studied compounds were changed synchronously (Figure 6). In the southwestern Atlantic, in the section through the Drake Passage to the western Scotia Sea, the study route was crossed the main Antarctic currents and fronts: the Antarctic Divergence, the Southern Polar Front, the Subantarctic Front [Antipov et al., 2014, Orsi et al., 1995. Politova et al., 2015.

That is allowed to fix a variability of all compounds. However, the most significant increase in concentrations was gained at the mouth of the La Plata River with the most abrupt rise -5.2 times in rates from 0.23 to $1.3 \mathrm{mg} / \mathrm{L}$ (Figure $6 \mathrm{~b}$ ). Depending on wind surge fluctuations and river runoff, the concentrations of the studied compounds vary. A considerable amount of biogenic SPM was found in the La Plata Bay [Politova et al., 2015] where the concentrations of $C_{\text {org }}$ in the SPM have reached $1.3 \mathrm{mg} / \mathrm{L}$, lipids and $\mathrm{HCs}-120$ and $80 \mu \mathrm{g} / \mathrm{L}$ respectively, Table 2). The Brazil Current in the mouth area of La Plata River meets a cold water current (Falklands Current, a branch of the Antarctic Circumpolar Current) and makes a contribution into increasing of concentration of all compounds.
When moving northward in the tropical waters of the Atlantic Ocean the content of SPM in oligotrophic waters almost did not vary remaining within the concentration a range $0.05-0.08 \mathrm{mg} / \mathrm{L}$. An increase of SPM up to $0.61 \mathrm{mg} / \mathrm{L}$ occurred in the surface waters in the area of arid flows under influence from the African deserts (Figure 6a).

North of $38^{\circ} \mathrm{N}$ the contents of SPM increased again. There was a chaotic increase in the content of all of the studied compounds, especially in approach to the English Channel in the surface coastal waters of Western Europe. In this area, a maximum increase in $\mathrm{HC}$ content was observed (up to $80 \mu \mathrm{g} / \mathrm{L}$ ) exceeding the value of maximum permissible concentrations (MPC) for petroleum hydrocarbons - $50 \mu \mathrm{g} / \mathrm{L}$.

SPM in the surface water was consisted mainly from biogenic particles represented by radiolarians, tintinids, and spores (Figure 7). Mineral particles were rare, mainly fragments of quartz and silicates. In the English Channel, the proportion of Si was $7.3 \%, \mathrm{SiO}_{2}$ was $46.9 \%$ (Figure 7 ).

\section{Discussion}

The study area was covered both humid temperate and equatorial regions, characterized by a low content of SPM in the atmosphere, and arid 

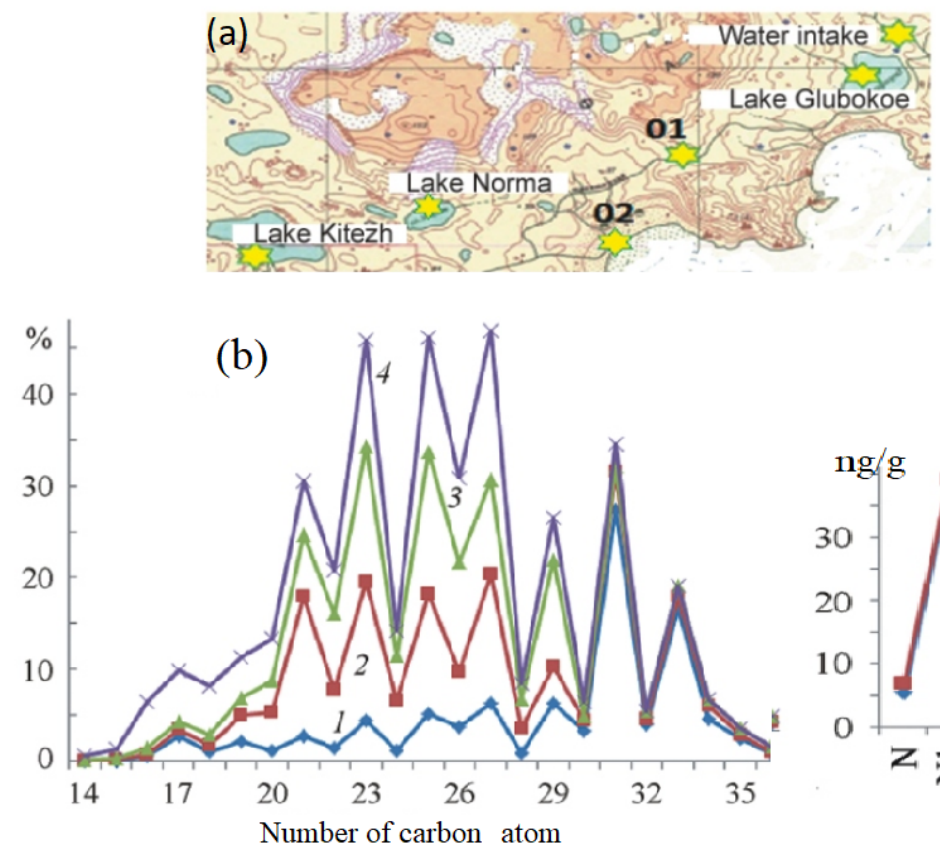

(c)

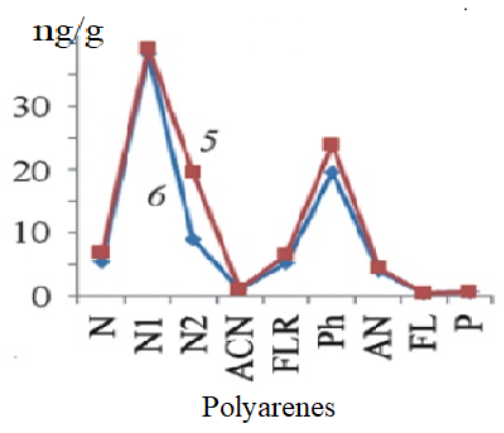

Figure 5. The composition of moss from Bellingshausen station: (a) the concentration of n-alkanes (of total): (1-3) Lake Glubokoe shore; (4) Lake Norma shore; (b) PAH concentration: $(5,6)$ Lake Glubokoe shore. N - naphthalene, N1 - 1-methylnaphthalene, $\mathrm{N} 2$ - 2-methylnaphthalene, ACN - acenaphthene, FLR - fluorene, Ph - phenanthrene, $\mathrm{AN}$ - anthracene, $\mathrm{Fl}$ - fluoranthene, $\mathrm{P}$ - pyrene.

regions, where atmospheric flows sharply increase. Therefore, the particle size distribution of aerosols and the number of particles in them changes abruptly and within wide limits (Figure 1). The aerosols were dominated by particles of $0.3-1 \mu \mathrm{m}$, that is consistent with earlier data [Croft et al., 2020, Diaz et al., 2018, Klyuvitkin, 2008, Nemirovskaya and Artem'ev, 2013. The small size of particles in the atmosphere is due to the fact that they are formed during the condensation of vapors or as a result of chemical reactions. The diffusion rate of such tiny particles is high enough, which creates a prerequisite for their coagulation and condensation [Shevchenko, 2006]. In some areas, the exceeding $5 \mathrm{\mu m}$ particles were absent (particularly, in the English Channel).

On the route of the expedition, the average concentrations and standard deviation from mean $(\sigma)$ for the $0.3-1 \mu \mathrm{m}$ fraction for different regions was increased in the sequence $(\mathrm{p} / \mathrm{L})$ : section along Antarctica $(6182, \sigma=5767)<$ coast of South America $(8682, \sigma=5176)<$ Canary upwelling $(16,618 ; \sigma=3697)<$ section from Antarctica to
S. America $(17,048 ; \sigma=10,805)<$ section from South Africa to Antarctica $(17,841 ; \sigma=13,251)$ $<$ Central part of the Atlantic $(23,754 ; \sigma=6842)$ $<$ European coast $(28,186 ; \sigma=11,363)$. The variability of aerosol concentrations was high and the standard deviation values were in a range from an average of $22 \%$ (Canary upwelling) to $83 \%$ (a section along Antarctica). The atmosphere is the most mobile and changeable of the Earth's geospheres, in which the flows of matter are rapidly changing due to the movement of air masses [Lisitsyn, 2014].

Reduced aerosol concentrations are confined to the coastal regions of Antarctica, since Antarctica is covered by a snow - ice sheet, which prevents the removal of particles from land. Local increase in concentration is associated with oases [Diaz et al., 2018, Nemirovskaya, 2006. Long-term monitoring of aerosols and soils on the Fildes Peninsula in Antarctica showed that a temperature played a key role in the transport of aerosols over long distances [Na et al., 2020].

In the Southern Hemisphere, the maximum concentrations of aerosol particles were detected in 

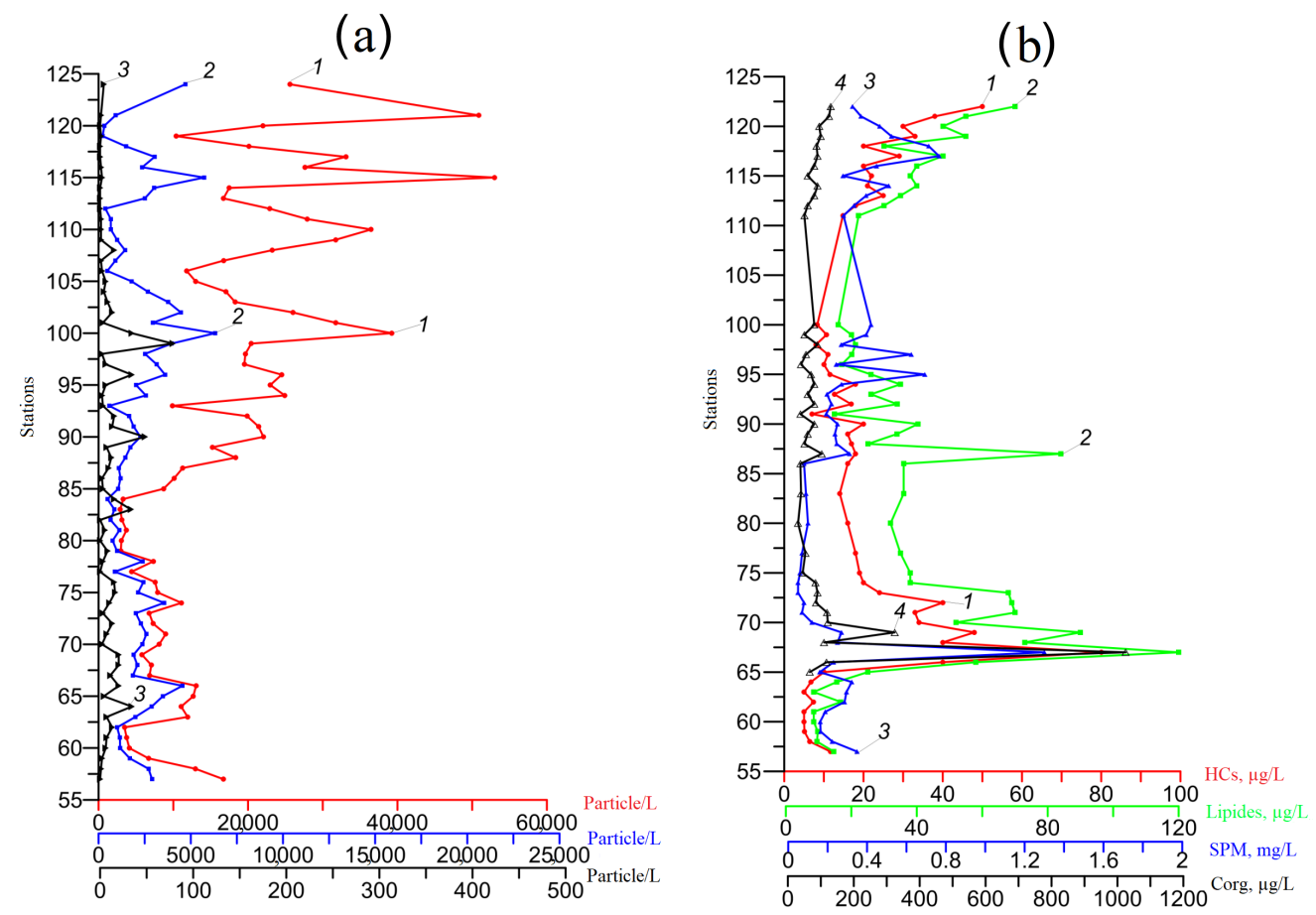

Figure 6. Distribution of aerosols (a); organic compounds and suspended particulate matter in surface waters (b) in the section from Antarctica to the English Channel. (a): $1-0.3-1,2-1-5$, and $3->5 \mu \mathrm{m}$, (b): $1-\mathrm{HCs}, 2$ - lipides, $3-\mathrm{SPM}, 4-C_{\mathrm{org}}$.

the northern arid part of the section (from Africa to the Southern Ocean, four degrees south of the African coast). The aerosol particle contents were depended on the speed of the wind blowing them out from the sea surface and thus, there was a correlation between these parameters with a high correlation coefficient $(r=0.82, n=14, P=0.95)$.

In particular in 2019 the contribution of surface aerosol particles of this fraction to the total number of particles was in a range $76-92 \%$. There was a high correlation $r=0.99(n=13, P=0.95)$ in the distribution of small particles $(0.3-1.0$ and $1-5 \mu \mathrm{m}$, Figure $3 \mathrm{a}$ ) and the particles of $>5 \mu \mathrm{m}$ were detected in some samples only. This is associated with the fact that the aerosol content increases as fast ice melts and fully depends on intensity of the cyclone activity near the coast. The blow-out of particles (especially of fine ones) from the icefree sea surface and from natural rocks on land takes place here. Therefore, the concentration of aerosol particles in the ice zone is lower than in the other regions. However, in the coastal regions (where snow was absent on the hills) the number of particles in the atmosphere increased. As a result, a dramatic increase in the concentrations of aerosol particles was observed in some samples.

At high latitudes, substances that enter the underlying surface with aerosols from the atmosphere can remain in snow and ice sheets for many years. Therefore, the snow and ice covers of Antarctica represent a natural tablet for collecting of atmospheric precipitation for a long period of time [Golobokova et al., 2016, Nemirovskaya and Shevchenko, 2020. In particular, an unusual distribution of SPM and OCs was found in the snow-ice cover of the Lake Kitezh at the station Bellingshausen. The snow contained a lot of suspended matter of mineral origin, due to the weathering of unprotected by snow soils [Nemirovskaya and Shevchenko, 2020.

In surface waters, the changes in hydrological parameters are of a meso- and micro-scale character. On the section along the Antarctic coast, the vessel's route passed in high-latitude waters south of $60^{\circ} \mathrm{S}$. An important role in the uneven distribution of the studied compounds is played by the vertical movements in the gyres, which are formed upon contact of waters of various types [Antipov and Klepikov, 2011. Nemirovskaya and Shevchenko, 2020. In the northern part of the sec- 

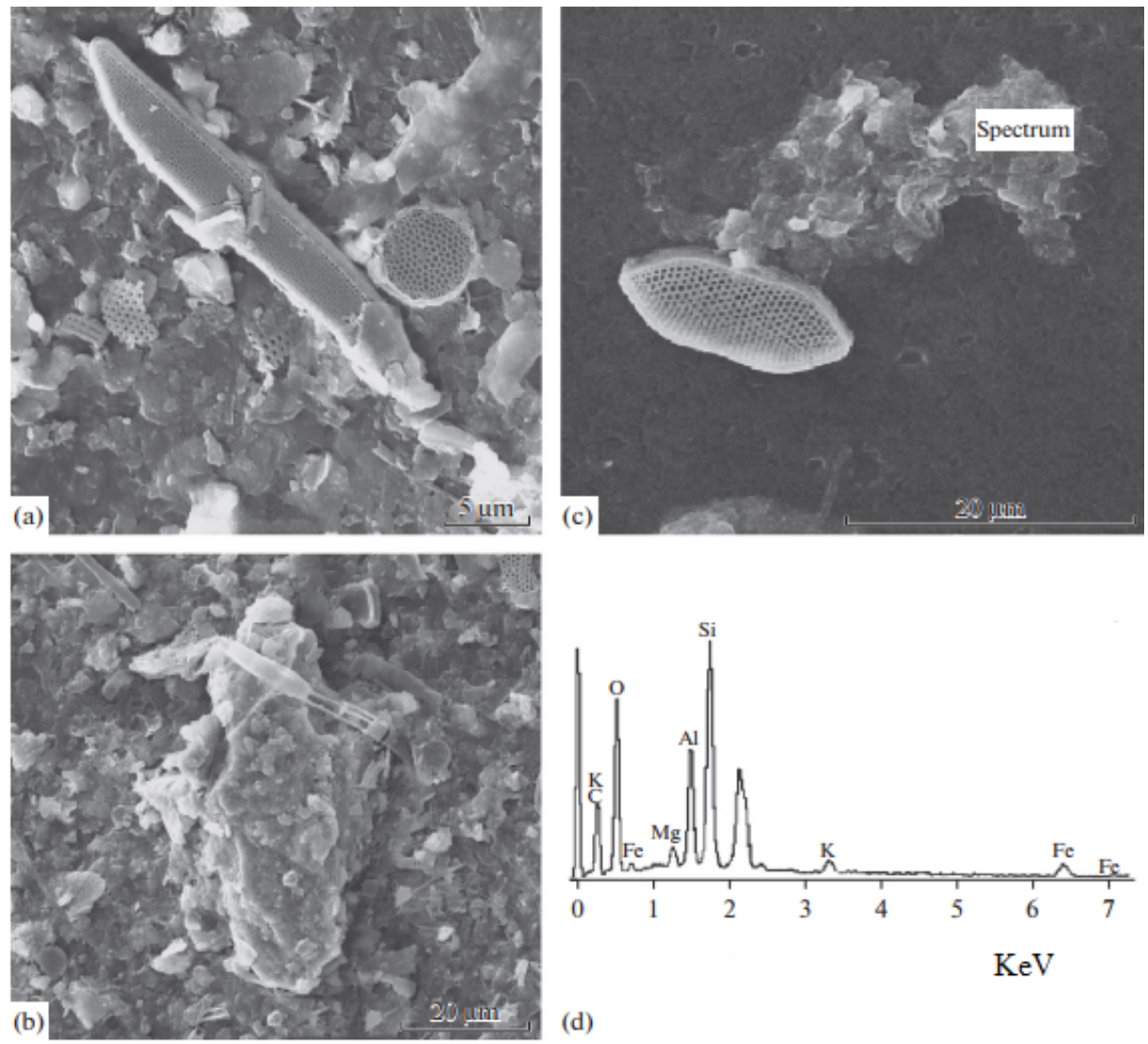

(d)

Figure 7. Composition of suspended particulate matter of surface waters extracted from different areas: (a) - La Plata Bay, (b) - influence zone of fluxes from arid regions of Africa, and (c) - Engllish Channel.
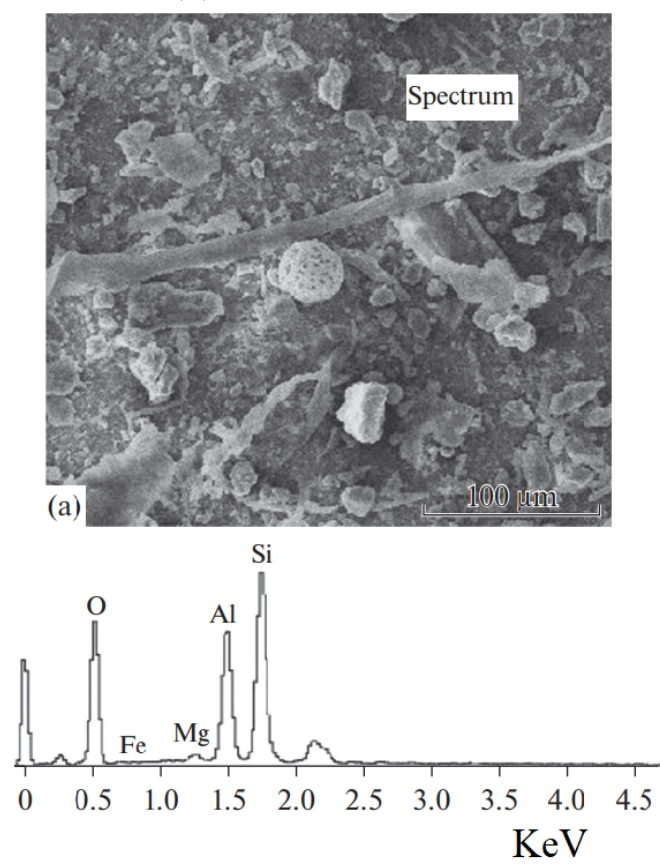
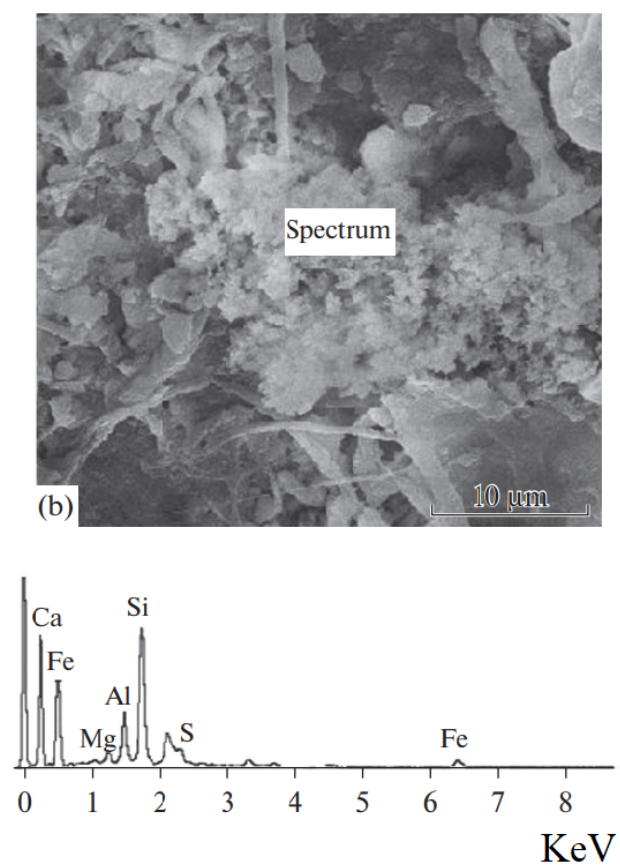

Figure 8. Composition of aerosol: (a) general view of sample near South America consisting of spores and biogenic detritus, with burning sphere in the center; (b) general view of sample near English Channel consisting of fibers, diatom fragments, with ash particles in center. The composition of mineral particles obtained using microprobe attached to scanning electron microscope [Nemirovskaya, 2017]. 
tion, the waters of the Antarctic circumpolar current come into contact with the high-latitude waters, that leads to the formation of a frontal zone and to decreasing in the concentrations of SPM, $C_{\text {org }}$ and, to a lesser extent, HCs.

When approaching the shores of Antarctica, a decrease in temperature is often observed, caused by the katabatic winds, which blow at an almost constant speed from the mainland towards the ocean [Antipov et al., 2014, Maslennikov, 2003. This wind effect leads to the drive of surface water from the edge of fast ice into the open sea and the rise of deep water masses rich in biogenic elements. However, due to the rapid exchange of waters, the phytoplankton community does not have time to become developed, that results to low concentrations of SPM, $C_{\text {org }}$, and $\mathrm{Chl} a$, the average concentrations of which were $0.184 \mathrm{mg} / \mathrm{L}, 46$ and $0.158 \mu \mathrm{g} / \mathrm{L}$ respectively.

The concentrations of all studied OCs are the subject of local variability, caused not only by hydrological factors, but also by the state of the ice cover, as well as the influx of aeolian material from the continent. When the vessel moves, the ice is destroyed and colonies of cryophilic microalgae are washed out from its bottom usually leading to an increase in the amount of SPM and OCs in the SPM.

In general, along the section in the Southern Ocean, a linear relationship was observed between the concentrations of SPM and Chl $a(r=0.88)$ [Nemirovskaya and Artem'ev, 2013. Nemirovskaya et al., 2013. In coastal waters near the seasonal ice boundary, the intensive development of phytoplankton led to high concentrations of Chl $a$ and, to a lesser extent, lipids and HCs (Figure $3 \mathrm{~b})$.

The increased aerosol concentrations in the section from Antarctica to South America are due to the fact that Patagonia is the center of the continental air formation of temperate latitudes - the South Atlantic anticyclone [Cabos et al., 2017]. Two types of circulation of Aeolian fluxes are widespread here: equatorial, with the powerful convection of air masses, where convergence of trade winds occurs, and subequatorial type with seasonal changes in equatorial and tropical air masses (trade-monsoon type) [Diaz et al., 2018].

The typical for the central part of the Atlantic transoceanic transport has a clear seasonality [Lisitzyn et al., 2016. In the summer-autumn sea- son, the zone of removal from the arid regions of Africa material extends to the north, reaching Barbados and Miami, where, according to the longterm measurements at aerosol stations, aerosol concentration maxima were noted from June to September [Goudie and Middleton, 2001]. In the winter-spring period, the matter transport routes move to the south with maximum in the region of French Guiana. The African and Asian lowlatitude deserts, the so-called dust belt, are the major source of dust for the entire world [Lauren et al., 2008. Mitra et al., 2020 Nemirovskaya and Titova, 2019. Uno et al., 2005. The dust belt includes the Sahara, arid and semiarid regions in Arabia and Central Asia, and the Taklamakan desert and Gobi in East Asia. During severe dust storms, Saharan dust crosses the Atlantic and affects both Americas [Afeti and Resch, 2000, Haywood et al., 2003. Klyuvitkin, 2008: Nemirovskaya and Titova, 2019 Prakash et al., 2015, Sakerin et al., 2017. In 2015 , the area of increase in the number of particles due to the influence of aerosol transport from arid regions of West Africa was lower than in 2019 $\left(4^{\circ}-15^{\circ} \mathrm{N}\right.$ in $2015,3.5^{\circ}-24^{\circ} \mathrm{N}$ in 2019$)$. The concentrations of aerosols and the average and maximum were similar (the average concentration for the $0.3-1 \mu \mathrm{m}$ fraction was $22,889 \mathrm{p} / \mathrm{L}$ in 2019 and $22,755 \mathrm{p} / \mathrm{L}$ in 2015, Table 1), since both expeditions took place in the spring, when the removal of aeolian material from arid regions was relatively low. However, with the proximity of sources of aeolian material., the amount of aerosols increases. In March 2017 during the removal of aerosol from the desert areas of the Arabian Peninsula, in the Gulf of Aden and the Red Sea the concentration of the aerosol for the $0.3-1 \mu \mathrm{m}$ fraction was significantly higher (up to 112,532 and up to $259,416 \mathrm{p} / \mathrm{L}$, respectively) than in the open areas of the Atlantic in 2015 and $2019(34,183$ and $33,824 \mathrm{p} / \mathrm{L}$, respectively) [Mitra and Sharma, 2002, Nemirovskaya, 2017. Prakash et al., 2015, Sakerin et al., 2017.

In addition, the amount of aerosols strongly depends on the direction of the wind, so their concentration can vary greatly with wind direction. So, in 2015, when the wind direction changed in the aqueous area of the Canary Islands, the amount of aerosols was decreased almost 4 times: from 17,761 to $4622 \mathrm{p} / \mathrm{L}$ for this fraction [Nemirovskaya, 2017]. The same was also observed in 2019 (Figure 4), however, due to the fact that the expedition route 
passed closer to the islands, the aerosol concentrations were 2 times higher (up to $36,471 \mathrm{p} / \mathrm{L}$ ).

The highest aerosol content along the survey route is confined to the northeastern part of the Atlantic, since Europe is one of the largest sources of anthropogenic aeolian inputs. Here, the local aeolian transport is a subject to significant variability due to the proximity of the coast and the change in wind direction. Therefore, the concentrations of the near-water aerosol in 2015 and 2019 for the 0.3-1 $\mathrm{\mu m}$ fraction were differed almost 3 times 15,319 and 55,389 p/L respectively (Table 1). For the same reason, the aerosol concentrations in the English Channel changed greatly: in May of 2017, when leaving the strait, a maximum of particles of this fraction was measured - 320,154 p/L, while in 2015 it was $147,067 \mathrm{p} / \mathrm{L}$ [Nemirovskaya, 2017, Nemirovskaya and Titova, 2018.

In 2015 at a time of the vessel movement in the Atlantic Ocean between Ushuaia and Gdansk the sampling of Aeolian material with help of the nets was carried out by us [Nemirovskaya, 2017].

It was found that the nature of the distribution of the counting and weight concentrations of drive aerosols was coincided. The obtained data on aerosol concentrations and their fluxes (up to $19.9 \mathrm{\mu g} / \mathrm{m}^{3}$ and up to $34.4 \mathrm{mg} / \mathrm{m}^{2}$ day) exceeded the obtained earlier results, when the fluxes in the arid region reached $20 \mathrm{mg} / \mathrm{m}^{2}$ day.

In the open regions of the Atlantic, the concentrations were decreased more than 10 times with distance from the continents, while predominantly mineral aerosols near the continents transformed to significantly more organic due to mechanical differentiation during the aeolian transport [Haywood et al., 2003, Lukashin et al., 2002. In this area, the terrigenous material prevails in the aerosols entering surface waters [Lisitsyn, 2014].

During many years, it was believed that Aeolian material was of significant importance only in the arid zones of land and that the evaporates (sedimentary rocks consisting of minerals such as rock salt and gypsum, formed by the evaporation of salt water in hot dry climates) were of prime importance, and in in the course of dissipation - the sands [Lisitsyn, 2014]. Our data showed that igneous clastic rocks were predominated in the mineral composition of aerosols: $39-72 \%$ (on average, $54 \%$ ). The presence of combustion spheres in coastal aerosols in the region of South America and ash particles approaching Europe indicated that aerosols were contaminated with pyrolysis products of organic raw materials.

Synchronous changes in the concentrations of aerosols, $C_{\text {org }}$ and HCs indicate the close sources in their formation. This is confirmed by the composition of HCs, in which high-molecular odd alkanes were dominated - indicators of terrigenous OM [Gogou et al., 1998, Nemirovskaya, 2006], as well as low Chl $a$ content. In the composition of alkanes, the values of the odd parity index - CPI (the ratio of odd to even alkanes in the high molecular weight region) in the arid region ranged from 6.3 to 8.8 [Nemirovskaya, 2006]. In the samples of another regions of the Atlantic, CPI values varied in a range from 1.8 to 3.4 , and in aerosols over the Mediterranean Sea, from 1.3 to 6.5 [Gogou et al., 1998 .

In the western part of the Atlantic Ocean, a larger concentration gradient of all studied compounds was confined to the mouth area of the La Plata River (Figure 6). Earlier [Nemirovskaya, 2017, a sharp increase in the content of all studied compounds (especially SPM - up to $9.46 \mathrm{mg} / \mathrm{L}$ and Chl $a-$ up to $2.481 \mu \mathrm{g} / \mathrm{L})$ was found for the mouth area of the Rio Colorado River in the El Rincon Bay (Table 2). HC concentrations changed to a lesser extent. Therefore, in terms of SPM, the $\mathrm{HC}$ content in the El Rincon Bay $(1.5 \mu \mathrm{g} / \mathrm{mg})$ was significantly lower than in the La Plata Bay $-27.7 \mu \mathrm{g} / \mathrm{mg}$ of SPM. The vessel passed a significantly eastern part of the Amazon estuary, so the influence of this river was not fixed. Nevertheless, as shown earlier, some part of riverine sedimentary material of this river spreads along the system of underwater canyons down to the depths of $5 \mathrm{~km}$ up to the Mid Atlantic Ridge, while the main part of riverine mass deposits on the shelf [Monin and Gordeev, 1988.

A synchronous change in their concentrations occurs in the open areas of the ocean. Increased HCs and Chl a contents in the area of $20^{\circ} \mathrm{N}$ are depended on an increase in water productivity in the Canary upwelling. In contrast to SPM and $C_{\text {org }}$, the HC concentrations were increased in the English Channel (in 2012-2015 up to $100 \mathrm{\mu g} / \mathrm{L}[\mathrm{Ne}$ mirovskaya, 2017]), that was caused by oil pollution. However, in the recent years, the $\mathrm{HC}$ content has also decreased in this area. 


\section{Conclusion}

The route of the vessel in March-June 2019, Africa-Antarctica-South America-English Channel, crossed different climatic zones with different hydrometeorological and hydrobiogeological conditions. In general., with the dominance of the 0.3 $1 \mu \mathrm{m}$ fraction, the average aerosol concentrations increased in the sequence: section along Antarctica $(6182, \sigma=5767)<$ coast of South America $(8682, \sigma=5176)<$ Canary upwelling $(16,618$; $\sigma=3697)<$ section from Antarctica to S. America $(17,048 ; \sigma=10,805) \approx$ section from South Africa to Antarctica $(17,841 ; \sigma=13,251)<$ Central part of the Atlantic $(23,754 ; \sigma=6842)<$ European coast $(28,186 ; \sigma=11,363)$. In each specific zone, the formation of aerosols, suspended matter, and organic matter at the boundary between the nearwater atmosphere and water occurred under the influence of various processes.

On the Africa-Antarctica section, during the formation of near-shore aerosol, the zonal flow of the Antarctic circumpolar current is influenced, which provides the interconnection and similarity of the regimes of the southern parts of the Atlantic and Indian Oceans. Therefore, the content of aerosol particles in this section correlated with the force of the wind blowing them out from the sea surface: $r=0.82, n=20$. The ascending and descending movements of surface waters change the content of suspended matter and organic matter. As a result, the greatest variability in the concentrations of aerosols and the studied components in surface waters occurs in the southern part of the section.

On the section in the coastal regions of Antarctica, due to the ice cover on the continent and the prevailing direction of wind from the mainland to the ocean, the minimum amount of aerosols in the near-surface layer of the atmosphere has been established. The relationship between aerosol concentrations and wind strength was much weaker $(r=0.34)$, since there is a local transport of aerosols in the absence of snow on the coastal hills. Therefore, a sharp increase in aerosols was observed in some areas, which determines their maximum dispersion in this section $(\sigma=5767,83 \%$ of the average). In surface waters, the local variability of all compounds is caused not only by hydrological factors, but also by the state of the ice cover, as well as the influx of aeolian material from the continent, since the increase in aerosol concentrations in the water area of St. Bellingshausen, was accompanied by an increase in the content of suspended matter, lipids and hydrocarbons in surface waters.

In the section from Antarctica to the English Channel, elevated aerosol concentrations off the coast of South America are associated with circumcontinental zoning (flows from Patagonia caused by the South Atlantic anticyclone). In addition, an increase in their concentrations took place in the La Plata Bay (Montevideo port), where the aerosol content $(11,914 \mathrm{p} / \mathrm{L})$ was determined at a wind speed of only $1.8 \mathrm{~m} / \mathrm{s}$. In surface waters, the distribution of SPM and OM in this area is influenced by the frontal zone of the La Plata River the ocean, where the concentration of the studied compounds changed depending on the value of the river runoff and wind surges.

With distance from the mainland in the Atlantic Ocean, the amount of aerosols decreased unevenly, depending on the direction of the wind. An increase in aerosols in the region of $17^{\circ}$ $18^{\circ} \mathrm{N}$, influenced by fluxes from African deserts (up to $30,000 \mathrm{p} / \mathrm{L}$ ), caused an increase in the content of suspended matter in surface waters (up to $0.61 \mathrm{mg} / \mathrm{L}$ ), but not lipids and hydrocarbons.

On the shelf of Western Europe, aerosol fluxes increased under the influence of anthropogenic inputs from industrial European regions, as well as from the combustion of marine fuel. In surface waters, there was a chaotic change in the concentrations of suspended matter and organic matter, especially when approaching the English Channel. In this area, the maximum increase in $\mathrm{HC}$ content was observed (up to $70 \mu \mathrm{g} / \mathrm{L}$, up to $214 \mu \mathrm{g} / \mathrm{mg}$ of SPM) caused by oil pollution.

Conflicts of Interest: The authors declare no conflict of interest.

Funding: The results of the studies were obtained within the state task (\# 0128-2021-0006); the sampling was supported by the Russian Antarctic Expedition, the generalization of results and the paper composition were supported by the Russian Science Foundation (grant 19-17-00234).

Acknowledgments. The authors are grateful to A. M. Titova and H. V. Kozina for their assistance in sampling, A. G. Boev and A. V. Khramtsova for assistance in conducting the analyses. The authors are grateful to the comments of the anonymous reviewers whose effort and suggestions have helped to make this a stronger contribution. 


\section{References}

Afeti, G. M., F. J. Resch (2000), Physical characteristics of Saharan dust near The Gulf of Guinea, Atmospheric Env., 34, 1273-1279, Crossref

Anglada, J. M., et al. (2020), Photoinduced Oxidation Reactions at the Air-Water Interface, $J$. Am. Chem. Soc., 142, 16,140-16,155, Crossref

Antipov, N. N., A. V. Klepikov (2011), Thermal structure of upper layer of an ocean between Africa and Antarctica according to the oceanographic data of the Arctic and Antarctic Research Institute (Russia) of 2004-2010, Input of Russia to the International Polar Year 2007/08, Oceanography and Marine Ice, I. E. Frolov (Ed.) p. 280-290, Paulsen, Moscow. (in Russian)

Antipov, N. N., A. I. Danilov, A. V. Klepikov (2014), Studies of the Southern Ocean within AARI Research Programs: From the "Poleks-Yug" Program, Probl. Arkt. Antarkt., 1, 65-85. (in Russian)

Arar, J., G. B. Collins (1997), Method 445.0. In vitro Determination of Chlorophyll " $a$ " and Pheophytin " $a$ " in Marine and Fresh water Algae by Fluorescence, Revision 1.2, U.S. Environmental Protection Agency, Cincinnati.

Brimblecombe, P., R. V. Martin, et al.

(2020), Factors controlling marine aerosol size distributions and their climate effects over the Northwest Atlantic Ocean region, Atmos. Chem. Phys. Discuss., 21, 1889-1916, Crossref

Butler, R. N., A. G. Coyne (2016), Organic synthesis reactions on-water at the organic-liquid water interface, Org. Biomol. Chem., 14, 9945-9960, Crossref

Cabos, W., D. V. Sein, et al. (2017), The South Atlantic Anticyclone as a key player for the representation of the tropical Atlantic climate in coupled climate models, Climate Dynamics, 48, 4051-4069, Crossref

Croft, B., R. V. Martin, et al. (2020), Factors controlling marine aerosol size distributions and their climate effects over the Northwest Atlantic Ocean region, Atmos. Chem. Phys. Discuss., 8, Crossref

Deacon, G. E. R. (1982), Physical and biological zonation in the Southern Ocean, Deep-Sea Res., 29, 1-15, Crossref

Demidov, A. B., V. I. Vedernikov, S. V. Sheberstov (2007), Spatiotemporal variability of chlorophyll $\mathrm{a}$ in the Atlantic and Indian sectors of the Southern Ocean during February-April of 2000 according to satellite and expeditionary data, Oceanology (Engl. Transl.), 47, 507-518, Crossref

Diaz, M. A., B. J. Adams, et al. (2018), Aeolian material transport and its role in landscape connectivity in the McMurdo Dry Valleys, Antarctica, J. Geoph. Res. Earth Surface, 123, 3323-3337, Crossref

Gogou, A. I., M. Apostolaki, E. G. Stephanou (1998), Determination of organic molecular markers in ma- rine aerosols and sediments: one-step flash chromatography compound class fractionation and capillary gas chromatographic analysis, J. Chromatography, 799, 215-231, Crossref

Golobokova, L. P., V. V. Polkin, et al.

(2016), Chemical composition of aerosol in the near-ground layer of the coastal zone of East Antarctica, Ice and Snow, 56, 177-188, (in Russian)Crossref

Gooseff, M. N., A. E. Blum, et al. (2002), Weathering reactions and hyporheic exchange controls on stream water chemistry in a glacial meltwater stream in the McMurdo Dry Valleys, Water Resources Research, 38, No. 12, 1279, Crossref

Goudie, A. S., N. J. Middleton (2001), Saharan dust storms: nature and consequences, Earth-Science Reviews, 56, 179-204, Crossref

Haywood, J., P. Francis, et al. (2003), Radiative properties and direct radiative effect of Saharan dust measured by the C-130 aircraft during SHADE: 1 . Solar spectrum, J. Geophys. Res., 108, No. D18, 8577, Crossref

Ivlev, L. S., Yu. A. Dovgalyuk (1999), Physics of Atmospheric Aerosol Systems, 256 pp. SPbSU, S.-Pb..

Klemas, V., $\quad$ X.-H. Yan (2014), Subsurface and Deeper Ocean Remote Sensing from Satellites: An Overview and New Results, Progress in Oceanography, 122, 1-9, Crossref

Klyuvitkin, A. A. (2008), Atmospheric aerosols and sedimentation in arid zones of the Atlantic Ocean, Dokl. Earth Sci., 421, 848-852, Crossref

Korshenko, A., (Ed.) (2019), Marine Water Pollution. Annual Report 2018, 190 pp. Nauka, Moscow. (in Russian)

Lappo, S. S., S. K. Gulev, et al. (2003), North Atlantic and its influence on the climate of Europe, $A c$ tual Problems of Oceanology p. 8-59, Nauka, Moscow. (in Russian)

Laurent, B., B. Marticorena, et al. (2008), Modeling mineral dust emissions from the Sahara desert using new surface properties and soil database, J. Geophys. Res., 113, No. D14218, 1-20, Crossref

Lisitzin, A. P. (2014), Modern concepts of sedimentation in the oceans and seas. Ocean as a natural recorder of geospheres' interaction, The World Ocean, Lobkovsky, L. I. et al. (Eds.), V. 2 p. 331571, Nauchnyi Mir, Moscow. (in Russian)

Lisitzin, A. P., A. A. Klyuvitkin, et al. (2016), Distribution and composition of suspended particulate matter in the Atlantic ocean: direct measurements and satellite data, Doklady Earth Sciences, 466, 221-224, Crossref

Lohmann, R., I. M. Belkin (2014), Organic pollutions and ocean fronts across the Atlantic ocean: A review, Progress in Oceanography, 128, 172-184, Crossref

Lohmann, R., J. Klanova, et al. (2013), PAHs on a West-to-East Transect Across the Tropical Atlantic Ocean, Environ. Sci. Technol., 4\%, 2570-2578, Crossref 
Lukashin, V. N., A. B. Isaeva, et al.

(2002), The geochemistry of sedimentary matter and particle fluxes in the Eastern Equatorial Atlantic, Geochem. Int., 40, 306-318.

Maslennikov, V. V. (2003), Climatic Fluctuations and Marine Ecosystem of Antarctic, VNIRO, Moscow. (in Russian)

Massel, S. R. (2007), Fundamentals of marine aerosols, Ocean Waves Breaking and Marine Aerosol Fluxes. Atmospheric and Oceanographic Sciences Library, 38 p. 207-228, Springer, New York. Crossref

Mitra, A., C. Sharma (2002), Indian aerosols: present status, Chemosphere, 49, 1175-1190, Crossref

Mitra, B., S. A. Papuga, et al. (2020), Allometric relationships between primary size measures and sapwood area for six common tree species in snow-dependent ecosystems in the Southwest United States, J. For. Res., 31, 2171-2180, Crossref

Monin, A. S., V. V. Gordeev (1988), Amazonia, 216 pp. Nauka, Moscow. (in Russian)

Na, G., Y. Gao, et al. (2020), Occurrence and sources of polycyclic aromatic hydrocarbons in atmosphere and soil from 2013 to 2019 in the Fildes Peninsula, Antarctica. Mar. Pol. Bul., 156, 111173, Crossref

Nemirovskaya, I. A. (2006), Organic Compounds in the Snow-Ice Cover of Eastern Antarctica, Geochem. Int., $8, \quad 825-834$, Crossref

Nemirovskaya, I. A. (2013), Oil in Ocean, Pollution and Natural Fluxes, 343 pp. Nauchnyi Mir, Moscow. (in Russian)

Nemirovskaya, I. A. (2017), Sedimentary matter and organic compounds in the aerosols and surface waters along the Transatlantic section, Geochem. Int., 55, 367-379, Crossref

Nemirovskaya, I. A., V. A. Artem'ev (2013), Particulate matter and components of the organic substance in the surface waters of the Southern and Atlantic oceans, Oceanology (Engl. Transl.), 53, 36-46, Crossref

Nemirovskaya, I. A., V. P. Shevchenko (2020), Organic Compounds and Suspended Particulate Matter in Snow of High Latitude Areas (Arctic and Antarctic), Atmosphere, 11, No. 928, 1-23, Crossref

Nemirovskaya, I. A., A. M. Titova (2018), Exchange of Suspended Matter and Organic Compounds at the Water Atmosphere Boundary in Indian and Atlantic Oceans, J. Environ. Sci. Nat. Res., 10, No. $3, \quad 1-3$, Crossref

Nemirovskaya, I. A., A. M. Titova (2019), Peculiarities of the distribution of suspended matter on the water - atmosphere geochemical barrier on the transoceanic sections, Oceanology, 59, 558-568, Crossref

Nemirovskaya, I. A., et al. (2013), Variability of suspended matter and organic compounds in surface waters of the Atlantic and Southern oceans according to the materials of the 57th Russian Antarctic Expedition, Probl. Arkt. Antarkt., 1, No. 95, 31-43. (in Russian)
Orsi, A., H. I. Whitworth, W. D. Nowlin, Jr. (1995), On the meridional extent and fronts of the Antarctic Circumpolar Current, Deep Sea Res., Part I, 42, 641-673, Crossref

Pedrosa-Pamiesa, R., M. H. Conte, et al. (2018), Carbon cycling in the Sargasso Sea water column: Insights from lipid biomarkers in suspended particles, Progress in Oceanography, 168, 248-278, Crossref Politova, N. V., V. A. Artem'ev, V. V. Zernova (2015), Distribution and composition of suspended matter at meridional section in the Western Atlantic, Oceanology (Engl. Transl.), 55, 889-898, Crossref Prakash, P., G. Stenchikov, et al. (2015), The impact of dust storms on the Arabian Peninsula and the Red Sea, Atmos. Chem. Phys., 15, 199-222, Crossref

Sakerin, S., L. Golobokova, et al. (2017), Spatiotemporal variability of aerosol characteristics on the route of the Indo-Atlantic expedition of the $\mathrm{R} / \mathrm{V}$ Akademik Nikolai Strakhov, Optics of the Atmosphere and Ocean, 30, 42-52, (in Russian) Crossref

Shevchenko, V. P. (2006), The Effect of Aerosols on the Environment and Marine Sedimentation in the Arctic, 226 pp. Nauka, Moscow. (in Russian)

Simard, R., J. Hasegawa, et al. (1951), Infrared spectrometric determination of oil and phenol in water, Anal. Chem., 23, 13,784-13,789, Crossref

Stokes, M. D., G. B. Deane, et al. (2013), Marine Aerosol Reference Tank system as a breaking wave analogue for the production of foam and seaspray aerosols, Atmos. Meas. Tech., 6, 1085-1094, Crossref

Uno, I., K. Harada, et al. (2005), Meteorological characteristics and dust distribution of the Tarim Basin simulated by the nesting RAMS/CFORS dust model, J. Meteorol. Soc. Jpn., 83A, 219-239, Crossref

Van Eijk, A. M., J. T. Kusmierczyk-Michulec, et al. (2011), Sea-spray aerosol particles generated in the surface zone, J. Geoph. Res., 116, 1-20, Crossref

Vasilenko, V. N., I. M. Nazarov, S. D. Fridman (1985), Monitoring of Snow Cover Pollution, Gidrometeoizdat, Leningrad, Russia. (in Russian)

Wozniak, A. S., A. S. Willoughby, et al. (2014), Distinguishing molecular characteristics of aerosol water soluble organic matter from the 2011 trans-North Atlantic US Geotraces cruise, Atmos. Chem. Phys., 14, 8419-8434, Crossref

Yoshizue, M., Y. Iwamoto, et al. (2019), Individual particle analysis of marine aerosols collected during the North-South transect cruise in the Pacific Ocean and its marginal seas, J. Oceanography, 75, 513-524, Crossref

\section{Corresponding author:}

Inna A. Nemirovskaya, Shirshov Institute of Oceanology RAS, 36, Nahimovskiy Pr., 117997 Moscow, Russia. (nemir44@mail.ru) 